\title{
Measuring the contribution of human capital to the development of the Catalan factory system (I830-6I)
}

\author{
JOAN R. ROSÉS \\ Department of History and Civilization, European University Institute, Via dei \\ Roccettini 9, San Domenico di Fiesole (Firenze), Italy
}

\begin{abstract}
The article argues that for a region adopting a technology from elsewhere, an existing stock of (relevant) human capital was essential to the rapid and successful adoption of the technology. But once the technology has been fully assimilated, increments to human capital would not be expected to be important in its further growth. Thus, Catalan industrialisation was possible because the level of human capital present in industry was enough to adopt and modify new technologies. Human capital stock was mainly the result of past investments in on-the-job training, and children's informal education took place in the workplace rather than the schoolroom. Therefore, the level of human capital present in the workforce was higher than literacy and schooling rates showed. However, evidence is also presented on the low contribution made by human capital to growth rates.
\end{abstract}

\section{Introduction}

Certain levels of human capital accumulation are almost universally regarded as a prerequisite for economic growth. In other words, the level of human capital is important in determining future growth rates and explaining differences in income per capita among countries. ${ }^{I}$ For example, Sandberg (1979, 1982) argues that the lack of human capital limited the opportunity of backward countries to grow rapidly during the last century. In a similar vein, many empirical studies for the twentieth century have also shown that the level of human capital is one of the major influences determining the capacity of nations to innovate and the speed of convergence (see for example, Romer 1986, Lucas 1988, I990, Barro and Salai-Martin 1992, Mankiw et al. 1992).

I In this article, the term human capital is not treated as a synonym for knowledge. According to Mankiw's definitions (Mankiw 1995, p. 35): 'Knowledge refers to society's understanding about how the world works. Human capital refers to the resources expended transmitting this understanding to the labour force'. 
In contrast, there is much discussion of whether the rate of growth of human capital explains actual growth rates. Thus, several economic historians have argued that human capital growth is less of an explanatory factor for the growth rates of the nineteenth century than of the twentieth (Abramowitz 1993, Crafts 1995). However, it should be stressed that in their accounts these authors have considered schooling and literacy, and not onthe-job training, which is more likely to reduce estimates for human capital during the nineteenth century when an important part of the workforce was illiterate but skilled, whereas it will raise the estimates for the twentieth century, when formal education was universally adopted and widespread. More prominently, during the early phases of industrialisation, training played a leading role in the development of skills among industrial workers and was widespread within proto-industrial households, workshops and factories.

This article revisits the contribution of human capital to early industrialisation using data drawn from the Catalan cotton industry. Specifically, its objective is to investigate: (I) how large the accumulation was of human capital prior to the emergence of the factory system, and (2) what the role of human capital during this process was. In other words, my aim is to study the level and growth effects of human capital.

The article argues that for a region adopting a technology from elsewhere, an existing stock of (relevant) human capital was essential to the rapid and successful adoption of the technology. But once the technology had been fully assimilated, you would not expect increments in human capital to be important in its further growth. Catalan industrialisation was possible because the level of human capital present in industry was enough to adopt and modify new technologies. The human capital stock was mainly the result of past investments in on-the-job training; and children's informal education took place in the workplace rather than in the schoolroom. ${ }^{2}$ Therefore, the level of human capital presented in the workforce was higher than literacy and schooling rates showed. However, evidence is also presented on the low contribution made by human capital to growth rates.

The motivations for this study are four. First, the industry and period provide a case study to examine the contribution made by human capital to the first stages of modern economic growth. Second, despite the importance of the Catalan and other Southern Europe regional cases, these have been habitually neglected in the literature. ${ }^{3}$ Third, as yet no scholar has considered human capital as a prerequisite for Catalan industrialisation and a broad inspection of schooling and literacy data seems to support this view.

2 Through this paper the term 'informal education' is treated as a synonym for training received before adult age.

3 At that time, other industrial regions in South Europe, but less industrialised than Catalonia, were Piedmont, Liguria, Lombardy, Naples and Calabria in Italy, Langedoc and Massif Central in France, and the South-East of Spain. 
For example, in 1860 Catalonia showed all the characteristics typical of countries with low levels of education: low literacy and primary schooling rates, large differences between the male and female levels of literacy and schooling, a strong concentration of schools in urban zones, low public investment in education, and many students at secondary and higher levels (Nuñez 1992, pp. 135, 292 and 298). Finally, in the debate over protoindustrialisation, the transmission of skills from proto-industry to the factory system has still not received adequate attention, while the contribution of cheap (unskilled) labour has been considered elsewhere.

The remainder of this article is organised as follows. Section 2 presents a simple framework to understand this methodology. The next section gives qualitative evidence on the levels of human capital present in the labour force. In addition, it describes the methods of education and training in the factories and asks whether workers' earnings were correlated with past investments in human capital. Section 4 discusses the effect of the spread of the factory system on the skills required for production. The following Section discusses the contribution of human capital to growth. Finally, Section 6 summarises and gives new perspectives on the role of human capital in the early phases of Catalan industrialisation.

\section{A methodology to estimate human capital}

In order to evaluate the contribution of human capital during the past century, a measure for the effects both of schooling and training is necessary. An alternative approach suggested by recent growth accounting exercises (for example, Young 1995) gives a simple solution to this problem through computing the quality of the labour force (i.e. the set of skills employed during production). There are two basic ideas behind this: (I) the quality of the labour force is enhanced by past investments in human capital, and (2) differentials in individuals' earnings are the consequence of these same investments. These two ideas are derived directly from the seminal arguments of human capital theory (Becker 1962, Schultz 1962, Mincer 1974). Put simply, the argument is that the income employed in enhancing human capacities raises the worker's earnings since it increases productivity per worker.

This argument is widely debated. Some authors have maintained that earnings differentials, even during the nineteenth century, are due to institutional constraints (see for example, on Catalonia, Camps 1995; and on Lancashire, Huberman 1996). As a result, human capital accumulation cannot be measured by computing individual earnings since they do not imply a direct relationship between age, experience, skill and productivity. For instance, Huberman has argued that in the Lancashire cotton industry, where standstills had higher costs and monitoring tasks were difficult, workers were paid with 'efficiency' wages; in other words, they were 
compensated for the absence of security in their jobs, for their monitoring tasks and to avoid shirking, with higher wages at the end of their lifetime's work. Therefore, employers and workers established a long-term and implicit contract where seniority criteria were employed to settle workers' earnings.

It is true that all pay structures in the Catalan cotton industry contained elements which hindered the perfect labour market. For the most part, however, these imperfections affected the difference in earnings between cotton spinning and weaving, rather than within a given industry. Moreover, in the Catalan cotton industry during this period, the flexibility of the labour force (the supply of labour was elastic even in the skilled occupations), the virtual absence of any kind of labour contract and the short lives of industrial firms could explain perfectly well why skills decided earnings and why institutional constraints had limited repercussions. Finally, it should be noted that a human capital explanation is not inconsistent with the presence of some imperfections in labour markets. Over time, earnings can increase with investment in human capital; but at one moment in time, the labour market can exhibit imperfections, like monitoring or shirking problems.

It should also be underlined that the evidence in Catalan cotton firms demonstrates that payment of 'efficiency' wages is unlikely to have affected average earnings significantly. The fact is that in the largest Catalan cotton firm (the España Industrial), which had about I,700 workers, the wages of skilled workers at the end of their working lives were significantly lower than at the peak of their physical strength (Camps 1995, table 7, pp. 204-5). In Barcelona factories, during periods of crisis, no seniority criteria were employed to fire workers (Cerdá I968, pp. 575-6) and piece-rates were different for each worker according to the quality and quantity of their production and not only according to their age. For example, in mechanical weaving, there were many different piece rates according to the productivity of the firm, the quality of workers' production, the number of pieces per hour, and so on (Cerdá I968, pp. 607-9). Furthermore, employers repeatedly rejected any kind of agreement with workers to establish piece-rate lists, with the argument that 'every worker must be paid according to his individual productivity and dexterity' (Junta de Fábricas I830, I834a and I835). ${ }^{4}$ The permanence of workers for long periods within one mill was unusual since the cotton companies were constituted for only short periods. Finally, the smaller size of Catalan cotton mills in comparison, for example, with Lancashire's mills, made the monitoring tasks relatively simpler for entrepreneurs or bosses. ${ }^{5}$

4 However, in the 1870 , several piece-rate lists were established by means of agreements between employers and workers (Nadal I991a, pp. 55-8).

5 For example, in 1850 , Catalonian cotton factories had on average 86 workers whereas those in England had I 7 I workers. The sources are: for Catalonia, Junta de Fábricas (1850) and for England, Sicsic (1994). 


\section{The levels of human capital in the labour force}

It is commonly accepted that certain levels of skill and technical competence are needed in the recipient country of new technologies (Rosenberg 1982, pp. $246 \mathrm{ff}$.). Moreover, it is pointed out that production or large scale importation of skills is very inefficient, at least compared with the production or importation of machinery (Sandberg I982, p. 696). In Catalonia, during this period, a large part of the cotton production shifted from domestic production, artisan shops and non-mechanised factories to mechanised factories that employed inanimate sources of energy instead of animal strength (Izard 1969, Maluquer 1976, Nadal I974 and 1991a). Moreover, despite Catalonia's overall low education and literacy levels, its cotton industry showed itself to be surprisingly efficient in embracing and rapidly modifying foreign technologies. ${ }^{6}$

In the first stages of the transition to modern industry, during the $1830 \mathrm{~s}$ and early I840s, foreign technicians and workers played a leading role in the adoption of new machinery since they installed and maintained new machinery and trained native workers (Ronquillo $185 \mathrm{I}-57, \mathrm{p}$. I28), but by the $\mathrm{I} 840$ os the latter had completely substituted the foreign workers in their tasks. Thus, from about the 1850 s on, Catalan factories could replace their machinery with new vintages, which were more sophisticated than the previous ones because they ran faster and operated with high pressure steam engines, without needing to appeal to foreign technicians (Comisión especial arancelaria 1867, Ferrer Vidal I875, Figuerola 1968). Therefore, after the initial period, Catalans developed the capacity to maintain their own machinery, adopted the new technologies and, obviously, ran them without any foreign help. Moreover, in the post-adoption phase, Catalan firms incorporated a stream of incremental developments and modifications to improve and adapt foreign technology to local requirements (Arau I855, Calvet 1857).

The stock of metal artisans and the active involvement of Catalan entrepreneurs were the two main factors that helped this rapid development of native technicians. During the proto-industrial period, in Barcelona and other Catalan industrial towns, many handicraft workshops made and repaired spares, small metal pieces and machinery, including cotton industry machinery (Madoz I846, Sayró I842, Comisión especial arancelaria I867, Figuerola I968, Nadal I99Ib). The artisans in these workshops were relatively (highly) skilled since they could perform many different tasks (i.e. the division of labour was not particularly important) under the supervision of the master (Comisión especial arancelaria 1867, Cerdá 1968, Figuerola 1968). With the spread of new cotton factories, cotton entrepreneurs

6 For example, from 1836 to 1840 the imports of modern cotton machinery from Britain and France were multiplied by six and the horsepower of steam engines from 1832 to I 848 were multiplied by 80 . The data came from Madoz (I846) and Figuerola (I968). 
recruited many metal artisans to fill the new machinery-maintenance posts. ${ }^{7}$ Thus, it can be argued that foreign technicians did not train uneducated native workers but specialised artisans and former apprentices of the metal workshops who would become factory technicians with only a short period of training. In addition, the Catalan entrepreneurs participated actively in the development and enlargement of this native highly-skilled workforce because the cost of recruiting and employing foreign workers was higher. An interesting example of this active involvement of Catalan entrepreneurs is given by the first modern cotton mill, the Bonoplata factory (established in I832), which not only produced cotton goods with the most modern technologies but also trained many young Catalans, who were then rapidly recruited by other new factories for the repair and maintenance of new machinery. ${ }^{8}$

In contrast to the machinery-maintenance sector, in the productive sector native workers performed all the productive skills from the beginning (Camps 1995, p. I23). Despite the fact that labour was still heterogeneous, factories preferred to employ workers from proto-industry, especially in weaving, because they were more productive than other workers (Junta de Fábricas 1835). According to contemporaries, their higher standards were the consequence of the many years of training they had experienced since they were children (Junta de Fábricas I830). It should also be stressed that proto-industrial workers could retain this advantage over other workers during the first stages of factory transition because there were more similarities than differences between the proto-industrial and factory machinery. For example, a contemporary comments that in mechanical weaving there are not apprentices since former handweavers can manage the new mechanical looms after a short explanation' (Cerdá 1968, p. 568).

However, not all workers in proto-industry were as skilled as the handweavers. Thus, the differences in skills between handweavers and handspinners were wider: handweaving was usually a high-skilled, full-time, male occupation with higher piece rates, whereas handspinning was a low-skilled, part-time, female and child occupation with lower earnings (Sayró 1842, Gutiérrez I834 and I837, Madoz I846). In handspinning, the proto-industrial household was the key element in the informal education of children whereas in handweaving apprenticeships were widely diffused, especially in

7 Figuerola (1968, p. 299) said: 'All cotton, silk or wool establishments had their own machinery workshop, which has its master and skilled workers, to repair any machinery breakdown suddenly. These workers have been educated in metal-industry workshops and factories (...) and they are actually ( 1849 ) natives of the country'.

8 For example, in 1833, the employers' organization congratulated Mr. Bonaplata 'for the efficiency of many young Catalans in learning the theory and practice of modern machinery in his factory in so far as these created the seedbed of the new mechanic artisans that will replace foreign artisans and make widespread their skills to the whole cotton industry' (Junta de Fábricas 1833). 
towns. Briefly, handweavers corresponded very well to the image of skilled artisans while handspinners were more akin to a cheap labour force.

A new system to educate the workforce was developed within the new mills. The necessity for a stable and skilled factory workforce, the low public investments in primary and technical education, and the decrease in protoindustrial workers who might be recruited by factories were the three main causes behind this innovation. In particular, the same spread of factories reduced the available stock of (skilled) proto-industry workers since they destroyed the old putting-out districts and jeopardised the survival of artisan workshops. Growing problems provoked by the cheap goods from new mills encouraged young proto-industrial workers to migrate to the new factories (Camps 1995, chapters 3 and 4). It should be noted that the rise of informal education was more rapid in spinning than weaving because the survival of handweaving during the period made the recruitment of skilled weavers for new mills easier (Cerdá 1968, p. 568).

The key element in the informal education of the new factory workers was the work of children and youths within the factories. ${ }^{9}$ Children entered the factories at the age of eight or nine, doing preparatory and auxiliary jobs (blowing, carding and roving). Over the following years, they worked beside a parent, relative or other experienced worker receiving little pay and sometimes changing occupation or even factory. In this way, many children gained a wide knowledge of the factories and their machinery. By the age of I5 or 16, the most proficient children were still attached to a work group receiving fixed weekly wages. At the age of 17 or 18 , many had acquired a high degree of dexterity and were ready to supervise their own work group as main mule-spinners (Cerdá 1968, p. 568). Therefore, during their time in the factories children not only worked but also received an informal education. As adults, they were able to obtain further increases in their earnings as their skills continued to improve. In spinning, for example, spinners began with throstles, afterwards moved successively to longer mules, and some of them finished their careers in the well-paid supervisory posts. ${ }^{10}$ Apprenticeship was also common in factories among highly skilled workers who filled the machinery maintenance jobs. For example, in 1856 at Barcelona, apprentices were 30 per cent of the workers in factory machinerymaintenance sections (Cerdá 1968, pp. 590-I). In contrast to the other factory children, these apprentices specialised in a specific job from their entry and did not receive any wages for their work.

Evidence on posts, earnings, opportunity costs and returns of informal education shows that human capital investment was made during the period in which children and young people worked in the factories. Former factory

9 There are many references to child work in the contemporary sources; see for example, Sayró (1842), Madoz (1846), Cerdá (1968), and Comisión especial arancelaria (1867).

10 This system of child training was very similar to the system employed in the cotton mills of Lancashire. On Lancashire, see Boot (1995). 
children filled the skilled posts in the factories because the workers who had not received any training as children could not develop these skilled tasks and were limited to unskilled jobs throughout their lives (Junta de Fábricas I 834b, Cerdá 1968 , p. 568). However, this does not mean that unskilled workers did not have opportunities to increase their earnings throughout their lives because they were given some sort of training within the factory and, therefore, were sometimes promoted from the simplest to semiskilled tasks. ${ }^{\text {II }}$

Table I shows the earnings in diverse jobs at Barcelona cotton mills, and the informal education and skills associated with these jobs. It may be seen that the largest maximum earnings and largest differentials between maximum and minimum corresponded to skilled jobs. Unskilled workers with no childhood education, in spite of the fact that they performed occupations with a considerable degree of physical exertion, expected to get lower

Table I. Selected cotton factory jobs: male yearly earnings (Barcelona, 1865).

\begin{tabular}{|c|c|c|c|c|c|}
\hline & Skills & $\begin{array}{l}\text { Child } \\
\text { Education }\end{array}$ & $\begin{array}{l}\text { Minimum } \\
\text { Earnings }\end{array}$ & $\begin{array}{l}\text { Maximum } \\
\text { Earnings }\end{array}$ & Difference \\
\hline Machinery-maintenance & HSK & AP & 2,791 & 4,996 & 2,205 \\
\hline Mechanical-weavers & SK & PR & I,0I6 & 3,853 & 2,837 \\
\hline Hand-weavers & SK & PR & 1,210 & 3,574 & 2,364 \\
\hline Jacquard-weavers & SK & PR\&AP & 1,694 & 3,570 & 1,876 \\
\hline Mule-spinners & SK & $\mathrm{CH}$ & 2,384 & 3,829 & $I, 445$ \\
\hline Factory labourer & USK & NO & 2,286 & 3,218 & 934 \\
\hline Carding-machines & USK & NO & $\mathrm{I}, 8 \mathrm{I} 4$ & 2,694 & 880 \\
\hline
\end{tabular}

Notes and sources: Values in Reales de Vellón (hereafter RV): Skills: HSK (highly skilled), SK (skilled), USK (unskilled). Informal education: PR (children working in proto-industry households); $\mathrm{CH}$ (children working in factories); AP (apprenticeships) and NO (any informal education). Minimum earnings corresponded to young workers and maximum earnings to experienced workers. The data source is Cerdá (1968, pp. 629-40).

earnings which would not increase much. Former apprentices obtained the largest minimum and maximum earnings because they received many specific skills and invested heavily in their education. However, a puzzling feature of these figures is the differences between the earnings of former proto-industry and factory boys, since the minimum earnings of former factory boys were higher than those of boys formerly in proto-industry whereas, in maximum earnings, these differences were not significant. This apparent anomaly can be explained by the fact that, at the beginning of their

"See interesting references to unskilled lifetime earnings in Cerdá (1968) and Camps (1995), p. 204. 
adult life, factory boys had more training in specific factory tasks than protoindustry boys although the latter were able to catch-up on factory boys' skills and earnings during their lifetime work at factories. In other words, the evidence shows that proto-industry trained workers for factories and the new machinery.

The work of children in factories had large opportunity costs for them and their families. Comparing the earnings of shoeshine boys with factory boys makes the analysis simple: the first was on average 3.5 Rv (Reales de Vellón) per day while in the factories boys received an average wage of $\mathrm{Rv} 2.5$ per day. Moreover, for a large part of this period, factory children were only paid Rv 2 per day and only at the age of fifteen or sixteen were they promoted to work in work groups, receiving wages of Rv 3 per day. ${ }^{12}$ The total opportunity cost of the period in the factories from eight to sixteen years was equal to three years of young adult (minimum) mule-spinners earnings ${ }^{13}$ and the opportunity cost of apprenticeship, which was not paid, was equal to about four years of young adult (minimum) machinery-maintenance earnings. ${ }^{14}$

Lifetime earnings may also be used to estimate the net returns of informal education within the factories. ${ }^{15}$ To compute the net returns of informal education, the adult yearly earnings of skilled workers in cotton factories has been compared with the yearly earnings of unskilled workers, throughout their lives. ${ }^{16}$ The net returns of skills acquisition are the difference between skilled and unskilled occupation earnings discounted to their present value. At the age of sixteen a skilled worker could anticipate earnings in present value terms of about $\mathrm{Rv} 206,556$ from his life as a factory worker, whereas a labourer could only expect about $\operatorname{Rv} 126,176$, that is to say 64 per cent of what he would have earned as a skilled worker.

\section{The effect of the spread of the factory system}

Scholars have largely debated whether the emergence of the factory system increased or decreased the demand for skills among workers. It is misleading

12 Shoeshining was the typical unskilled job with absolute free-entry. For example, Cerdá (1968, p. 599) comments that many factory boys also worked at shoeshining on Sundays because the factories were closed.

${ }^{13}$ Assuming that children began to work at eight years of age; the number of days of work in the factories were 227 while shoeshines worked for 349 ; the discount rate assumed to be 6 per cent, and the wages remained constant, as the sources indicate for 1855 . The actual opportunity cost of working within the factories at the age of sixteen is equal to the discounted difference between shoeshine and factory wages. Sources for data: Cerdá (I968).

${ }^{14}$ Under the same assumptions but considering the wage of apprentices equal to zero.

is Recently, Boot (1995, p. 283) suggested that observing the lifetime earnings profiles of workers it is possible to measure skills formation during the nineteenth century in Lancashire.

${ }_{16}$ The methodology and assumptions have been described in footnote 13 , but the data are the time series from 1847 to 1887 computed by Camps (I995, table 7, p. 204). 
to argue that all workers in proto-industry were skilled since there was an incipient division of labour such that some simple productive tasks were carried out separately by unskilled workers and at least some artisanal jobs were relatively unskilled. ${ }^{17}$ However, it is true that division of labour increased with the spread of factories. In particular, in proto-industry some workers could not only make the final goods but also produced, installed or maintained machinery; whereas in new factories, the machine-installation, machine-maintenance and production sections were run by specialised groups of workers (Goldin and Katz 1996).

The labour force in the cotton mills during this period was a combination of highly skilled, skilled and unskilled workers. ${ }^{18}$ In the preparatory section, where raw cotton was cleaned and prepared for spinning, unskilled workers (females and children) were monitored by foremen, who were the only skilled workers in the section. On the shop floor of spinning rooms, work groups were common and overlookers did not monitor the effort of workers. In work groups, each spinner worked with one or two piecers, unskilled workers who mended broken threads during spinning operations. From about the I850s, the rapid substitution of mule-jennies by self-actors did not reduce the importance of work groups and, according to the Catalan sources, did not alter the structure of labour much during the first years (Cerdá 1968 , pp. 595-8). On average, in spinning mills, which traditionally comprised preparatory and spinning sections, the proportions were one skilled worker (overlooker or spinner) to three or four unskilled workers. ${ }^{19}$ In weaving, the work group was less common than in spinning and many experienced weavers worked alone everywhere whereas unskilled workers mainly women and children monitored by foremen - carried out the auxiliary tasks in this section. The increase in mechanical looms altered the relation between the number of weavers and auxiliary workers since in handweaving (with dandy or jacquard looms) the ratio was one weaver to two auxiliary workers, whereas in mechanical-weaving it was one auxiliary worker to three or four weavers (Comisión especial arancelaria I867, pp. 45-6, Cerdá 1968, pp. 607-13). Machinery-maintenance and enginecontrol tasks were also carried out by work teams, which normally constituted several artisans. Interestingly, the corps of machinists was highly skilled because the steam engines were very unpredictable. Furthermore, all factories had several labourers who did some general tasks. Finally, many factories also had their own group of clerks and other white collar workers such as accountants, designers and so on.

${ }_{17}$ See the data that appears at Cerdá (1968, p. 609-13).

${ }^{18}$ The following description of cotton mills is based on several historical sources: Arau (1855), Calvet (1857), Cerdá (1968), Comisión de Fábricas (1846), Comisión especial arancelaria (1867), Comisión del Gobierno de S.M. (I84I), and Ronquillo (I85I-7).

19 According to Cerdá in Barcelona's mills ( 1856 ) there were $I, 450$ spinners, $I, 450$ piecers and 2,110 workers involved in the preparatory stages (Cerdá 1968, pp. 595-8). 
There are several procedures for investigating changes in workforce skills. The most simple is to compute the proportion of adult males, adult females and children. It is a commonplace that, during this period, women received less formal or informal education than men and, therefore, on the average they were less skilled. ${ }^{20}$ Similarly, on-the-job training for females lasted less long than for males because they tended to abandon the factory much earlier (sometimes after marriage) and had more frequent and longer absences for illness. ${ }^{21}$ However, women's skills cannot be studied without a proper understanding of their heterogeneous situation within the cotton industry. In proto-industry, women predominated in handspinning and auxiliary tasks but not in handweaving (i.e. the fairly unskilled occupations). By contrast, in mills, in spite of their preponderance in low paid and unskilled jobs, many women were frequently to be found in skilled jobs such as mulespinning or mechanical-weaving, where they were paid the same piece-rates as men. ${ }^{22}$ Here, the main difference between males and females was that males filled the extra-paid posts in longer mules, monitoring, white-collar and machinery-maintenance. There was a large spectrum of variables that influenced this segregation of females from extra-paid posts; occasionally the physical exertion required was an unavoidable entry barrier for females (e.g. in longer mules), ${ }^{23}$ in others, women had not been apprentices or had no formal education (e.g. in machinist posts), and in others they were not recruited simply for social reasons (e.g. as overlookers). ${ }^{24}$

In Table 2 it is easy to appreciate the process of substitution of females and children by males. This process is related to the fact that the typical female occupations in proto-industry, especially handspinning, disappeared more rapidly than male occupations, such as handweaving, while many new jobs created with the arrival of factories were filled exclusively by males (e.g. engine-driver, overlooker, dockers).

Data on sex, age, and skills has been put together to establish the

${ }^{20}$ According to Cerdá (1968, pp. 562-70), in Barcelona's workforce in 1856 about 75 per cent of males were skilled whereas only about 48 per cent of females were. Moreover, only 14 per cent of apprentices were female.

${ }^{2 \pi}$ However, these results might be different if there were strong differentials in shirking among men and women, but on that aspect the data are not yet available.

${ }^{22}$ Cerdá (I968, p. 646) lists 16 jobs where he points out that females had the same competence as males. Only in three of the 16 , corresponding to mule-spinners, self-acting spinners and mechanical-weavers, did females have the same salary as males. This evidence proves that in cotton mills the labour market in skilled jobs was not generally segmented by sex.

${ }^{23}$ The fact is that 'the (spinning) mule was extended until it made more efficient use of the adult male worker's physical capacities' (Huberman 1996, p. 35).

${ }^{24}$ Here, since many females monitored their own work group in spinning with success, it cannot be argued that they did managerial tasks worse than males and, consequently, they were not recruited for monitoring posts. This contradicts the views of Lazonick (1979) and Huberman (I991). 
Table 2. Composition of the labour force in full-time equivalent employment, $1830-61$.

\begin{tabular}{lllll}
\hline \hline & Male & Female & Children & Total \\
\hline I830 & 19,579 & 19,628 & 9,205 & $48,4 \mathrm{II}$ \\
Per cent & 40.44 & 40.54 & 19.01 & 100.00 \\
I840 & 23,480 & 24,718 & $1 \mathrm{I}, 684$ & 59,882 \\
Per cent & 39.21 & $4 I .28$ & 19.51 & 100.00 \\
I850 & 32,655 & 18,662 & 7,637 & 58,955 \\
Per cent & 55.39 & 31.65 & 12.95 & 100.00 \\
I86I & 29,720 & 13,047 & 3,682 & 46,448 \\
Per cent & 63.98 & 28.09 & 7.93 & 100.00 \\
\hline \hline
\end{tabular}

Notes and sources: See Appendix I.

proportion of skilled and unskilled workers in the cotton industry, both factory and proto-industry. Here, eight categories have been distinguished. Five categories correspond exclusively to factory workers: highly skilled male workers, skilled male workers, unskilled male workers, skilled female workers, and unskilled female workers. Proto-industry workers are divided into only two categories: male and female. Finally, the children category corresponds to workers under the age of $\mathrm{I} 6$ in proto-industry and factories.

The factory categories have been defined in the following way: highly skilled workers are workers employed in non-productive jobs (e.g. administration, maintenance) and had normally already received a formal education and/or an apprenticeship; skilled workers are those employed in the processes of production where they were in charge of machines (e.g. spinners, weavers) and who had normally been trained within the same factories or in proto-industry; and unskilled workers are those employed in the process of production in auxiliary tasks (e.g. carders, cleaners, dockers) and who were not trained as children in the cotton industry. Highly skilled and unskilled workers were wage-earners while skilled workers (and also proto-industry workers) were paid piece-rate (Comisión especial arancelaria I867 and Cerdá 1968). Moreover, skilled workers managed work groups while the unskilled were monitored by foremen or other workers.

The most outstanding result that emerges from Table 3 is that in $186 \mathrm{I}$, despite thirty years of factory workforce development with rapid growth rates (at on average about 5 per cent per year), proto-industry occupations were still important, with about 55 per cent of the total. Until the I850s, the development of the factory workforce was accompanied by a parallel increase in proto-industry labour because during these first twenty years handweaving benefited from the expansion of mechanical spinning, which decreased the price of yarn, and increasing markets for cotton goods. In effect, handweaving was only strongly damaged by the factory expansion of 
Table 3. Skills composition of adult workforce in full-time equivalent employment, I830-6I.

\begin{tabular}{|c|c|c|c|c|c|c|c|}
\hline & $\begin{array}{l}\text { Factory } \\
\text { highly skilled } \\
\text { male }\end{array}$ & $\begin{array}{l}\text { Factory } \\
\text { skilled } \\
\text { male }\end{array}$ & $\begin{array}{l}\text { Factory } \\
\text { unskilled } \\
\text { male }\end{array}$ & $\begin{array}{l}\text { Proto- } \\
\text { industry } \\
\text { male }\end{array}$ & $\begin{array}{l}\text { Factory } \\
\text { skilled } \\
\text { female }\end{array}$ & $\begin{array}{l}\text { Factory } \\
\text { unskilled } \\
\text { female }\end{array}$ & $\begin{array}{l}\text { Proto- } \\
\text { industry } \\
\text { female }\end{array}$ \\
\hline 1830 & 64 & 120 & 123 & I9,27I & $\mathrm{I}, 045$ & 2,493 & 16,090 \\
\hline Per cent & 0.16 & $0.3 I$ & $0.3 I$ & 49.15 & 2.67 & 6.36 & 41.04 \\
\hline I 840 & 212 & 486 & 402 & $22,38 \mathrm{I}$ & 3,394 & 8,049 & 13,275 \\
\hline Per cent & 0.44 & I.OI & 0.83 & 46.44 & 7.04 & 16.70 & 27.54 \\
\hline 1850 & 604 & 3,128 & 1,122 & 27,803 & 2,272 & 4,629 & II, 763 \\
\hline Per cent & 1.18 & 6.10 & 2.19 & 54.18 & 4.43 & 9.02 & 22.92 \\
\hline I86I & 907 & 7,915 & 1,635 & I9,26I & 2,885 & 5,073 & 5,088 \\
\hline Per cent & 2.12 & $18.5 I$ & 3.82 & 45.04 & 6.75 & 11.86 & $I I .90$ \\
\hline
\end{tabular}

Notes and sources: see Appendix 2.

the 1850 , when mechanical looms took over coarse-medium cloth production, but handweavers remained numerous until at least the 1870 , when Catalan mechanical looms also began to produce fine cloth (Comisión especial arancelaria, 1867). Therefore, due to this partial substitution of handweaving by mechanical weaving, highly skilled hours formed only 2 per cent of the total hours in $186 \mathrm{I}$ and skilled hours (male and female) formed 26 per cent. ${ }^{25} \mathrm{~A}$ secondary result is that the growth of a skilled (highly skilled and skilled) workforce was more rapid than the unskilled one, which only represents a minor portion of the total workforce at the end of the period.

The final test concerning the demand for skills can only be made by computing the changes in the remuneration of productive factors (raw labour, human capital and physical capital). Two of the possible outcomes are related to changes in the demand for skills: (I) if raw labour and physical capital remunerations rose while human capital dropped, the new machinery had a de-skilling effect, and (2) if human and physical capital remunerations increased while raw labour diminished, the new machinery increased the demand for skilled labour.

Human capital remuneration is assumed to be that of labour minus the part of raw labour. Raw labour remuneration is the result of the sum of the total of hours of male work multiplied by the male hourly wage of unskilled cotton workers from 16 to 20 years old, with the total hours of female work

${ }^{25}$ In response to these features, one might argue that human-capital supply bottlenecks restricted the development of the factory system. However, the available evidence gives little support to this assertion because, in weaving, the survival of a large number of artisans guaranteed the continuous availability of skilled workers while in spinning, where artisans had practically disappeared in only a few years (by the mid-I840s), the number of children trained at the factories largely exceeded the demand for new skilled workers from the same factories. 
multiplied by the female hourly wage of unskilled cotton workers from 16 to 20 years old, plus children's earnings. This measure of raw labour is based on three points: (I) unskilled cotton workers from 16 to 20 years were not trained or educated, (2) the differences between males and females must be reflected in the account, and (3) the measure of raw labour must be based on data from the same cotton industry to avoid distortion by labour market failures. ${ }^{26}$

The human capital share has also been separated into two sub-shares. Specifically, the share of childrens' education is the total initial hourly wage of skilled workers (separate for male and female) minus the corresponding raw labour wage. The initial hourly wage of skilled workers is the wage of skilled workers from 16 to 20 years old. This value included two types of education, which unfortunately cannot be separated with the data available: formal (schooling) and informal (mainly household education and apprenticeship). Next, the share of on-the-job training during adult age has been computed as equal to the labour input share minus the raw labour share and the education share. Thus, the assumption is that age decides training and, therefore, wage profiles. ${ }^{27}$

Table 4 tends to confirm more than to reject the results of the previous table but it also highlights strong differences between cotton spinning and weaving. In spinning, the process of substitution of raw labour by physical and human capital was clear since the remuneration of raw labour fell during the period (from 36 per cent to only about 22 per cent) while human capital and physical capital grew. However, it should also be noted that, despite its increase, the share of human capital in value-added payments remained less than that of raw labour. In addition, education grew more rapidly than adult training and, consequently, the main source of new human capital was childrens' education. In weaving, the results indicate that the relative employment of human capital (skilled workers) increased over time.

\section{The contribution of human capital to growth}

The results presented in Section 4 suggest that the contribution to growth (i.e. the growth rate effect) of human capital might be small. In this section, in order to determine the robustness of the results above, I investigate the same issue using a different methodology. In particular, I use a growthaccounting framework, which is the typical methodology of much of the empirical literature on long-run growth, to determine what fraction of the

\footnotetext{
${ }^{26}$ In contrast, other economic historians (e.g. Crafts 1995) have established the remuneration of raw labour as the wage of agrarian labourers. It should be noted that, in this case, the average male agrarian wage in the province of Barcelona (Garrabou et al. I99I, pp. 40-3) was about 90 per cent of that of unskilled workers in the cotton industry. 27 This assumption is proved empirically by Mincer (1989).
} 
Table 4. Remuneration of production factors in value-added (per cent).

\begin{tabular}{|c|c|c|c|c|c|c|}
\hline & $\begin{array}{l}\text { Raw } \\
\text { labour } \\
\text { I }\end{array}$ & $\begin{array}{l}\text { Children } \\
\text { education } \\
2\end{array}$ & $\begin{array}{l}\text { Adult } \\
\text { training } \\
3\end{array}$ & $\begin{array}{l}\text { Human } \\
\text { capital } \\
4=2+3\end{array}$ & $\begin{array}{l}\text { Total } \\
\text { labour } \\
5=\mathrm{I}+2+3\end{array}$ & $\begin{array}{l}\text { Capital } \\
6\end{array}$ \\
\hline \multicolumn{7}{|l|}{ Spinning } \\
\hline I830 & $35.9 \mathrm{I}$ & 4.16 & 4.78 & 8.94 & 44.85 & 55.15 \\
\hline I 840 & 32.56 & 7.53 & 6.03 & 13.56 & 46.12 & 53.88 \\
\hline I850 & 26.46 & 9.37 & 7.87 & 17.24 & 43.71 & 56.29 \\
\hline I86I & 22.06 & 10.68 & 8.55 & 19.23 & 41.29 & 58.71 \\
\hline Average & 29.25 & 7.93 & $6.8 I$ & 14.74 & 43.99 & 56.01 \\
\hline \multicolumn{7}{|l|}{ Weaving } \\
\hline 1830 & 46.78 & $\mathrm{I} 6.8 \mathrm{I}$ & I9.66 & 36.47 & 83.25 & I6.75 \\
\hline I 840 & 46.42 & I6.80 & I9.47 & 36.27 & 82.68 & 17.32 \\
\hline I850 & 46.II & 19.96 & 20.33 & 40.28 & 86.39 & $13.6 \mathrm{I}$ \\
\hline I 86I & 39.47 & 22.76 & 27.86 & 50.62 & 90.09 & $9.9 \mathrm{I}$ \\
\hline Average & 44.69 & 19.08 & 21.83 & $40.9 I$ & 85.60 & 14.40 \\
\hline
\end{tabular}

Notes and sources: See Appendix 3: the sections devoted to human capital, raw labour and shares. Value added is equal to sectoral output minus intermediate inputs.

output growth rate can be attributed to human capital and what fraction can be attributed to other inputs and innovation.

Growth theory published in recent years has changed the conventional model of economic growth significantly, giving emphasis to human capital as an independent input (see for example, Rebello 1991, and the review of the literature in Barro and Sala-i-Martin 1994). Thus, growth is not only a function of physical capital, labour, and innovation but also of human capital. Moreover, the recent literature on growth accounting has incorporated improvement in the analysis by considering intermediate inputs in industry-based analysis, and subdividing inputs by type and weighting each type by its imputed return. I have combined the new theory with the above methodological improvement in a single growth-accounting equation by dividing labour into raw labour and human capital parts, simultaneously considering changes in input quality. Specifically:

$$
\begin{aligned}
& \ln Q_{T}-\ln Q_{T-\mathrm{I}}=\theta_{X}\left[\ln X_{T}-\ln X_{T-\mathrm{I}}\right]+\theta_{K}\left[\ln K_{T}-\ln K_{T-\mathrm{I}}\right]+ \\
& \theta_{L}\left[\ln L_{T}-\ln L_{T-\mathrm{I}}\right]+\theta_{H}\left[\ln H_{T}-\ln H_{T-\mathrm{I}}\right]+T F P_{T-\mathrm{I}, T}
\end{aligned}
$$

where:

$$
\theta_{i}=\mathrm{I} / 2\left[\theta_{i, T}+\theta_{i, T-\mathrm{I}}\right]
$$

Here $\mathrm{Q}$ is output, $\mathrm{X}$ is physical intermediate inputs, $\mathrm{K}$ is capital, $\mathrm{L}$ is labour, $\mathrm{H}$ is human capital, TFP is total factor productivity and the $\theta_{i}$ 
denote the share of each input in total factor payments. The index of TFP $\left(T F P_{T-1, T}\right)$ is a measure of the increase in output attributable to innovation; in other words, it is the increase in output triggered by a time-related shift in the production function.

The appropriate measure of physical capital, human capital and labour inputs is the flow of services emanating from these inputs. Moving to labour input, one can reasonably assume that the flow of services is proportional to the total hours of work. The contribution of the raw labour input is estimated as the arithmetic sum of hours worked, with no adjustment for labour quality, multiplied by their share in total payments. Likewise, the contribution of human capital is computed as an index of human capital, where the price part is the remuneration of human capital in each category of workers and the quantity part is the quantity of hours worked crosstabulated by sex, age and skills. Moreover, each category is weighted by its earnings premium over the raw labour wage (i.e. the wage of unskilled workers from 16 to 20 years). Specifically, human capital rises if the components with higher flows of labour input per hour worked grow more rapidly, and falls if components with lower flows per hour grow more rapidly. For example, in this paper it is hypothesised that, because the average wage of a male highly skilled worker was higher than that of a male skilled worker, the direct substitution of a skilled male worker by a highly skilled male worker entails an increase in the use of human capital in the aggregate production function.

Table 5 compiles the contributions to growth in the Catalan cotton industry. Two main conclusions emerge from these results: (I) TFP was the factor that grew most rapidly, and (2) the growth of human capital was slow or, in some cases, even negative. Consequently, Table 5 tends to confirm more than to reject the results obtained previously with the descriptive techniques.

Some interpretations of TFP growth in the Catalan cotton industry can be derived from these results. The first implication is related to the fact that TFP appears clearly as the main ingredient in the years of rapid expansion of the output. These years of strong expansion of output, and TFP, were associated with important structural changes in the sector that altered the organisation of the firms, markets and labour. The main change during these years was, precisely, the emergence of the factory system. In other words, the substitution of putting-out by the factory system formed the basis of the development of industrialisation and the growth of industrial output.

The second implication is that innovation in the light industries in the nineteenth century had strong multiplicative effects. The adoption of some innovations in the cotton industry produced large effects in the growth of output. Contemporary experience is quite different because to achieve greater effects, long-term research projects and extensive human capital are necessary. In the nineteenth century, the effects of innovation were greater 
Table 5. Augmented Solow-type growth accounting, (I830-6I).

\begin{tabular}{lllllll}
\hline \hline & & \multicolumn{5}{c}{ Contributions to growth (per cent per year) } \\
\cline { 3 - 7 } & Output & $\begin{array}{l}\text { Physical } \\
\text { inputs }\end{array}$ & $\begin{array}{l}\text { Physical } \\
\text { capital }\end{array}$ & $\begin{array}{l}\text { Human } \\
\text { capital }\end{array}$ & $\begin{array}{l}\text { Raw } \\
\text { labour }\end{array}$ & TFP \\
\hline Spinning & & & & & & \\
I830-40 & 7.02 & 3.74 & 0.92 & 0.20 & 0.45 & I.7I \\
I840-50 & 7.65 & 4.50 & I.52 & 0.04 & -0.38 & 1.96 \\
I850-6I & 3.29 & 2.03 & 0.84 & 0.00 & -0.17 & 0.59 \\
I830-6I & 5.90 & 3.32 & I.I2 & 0.11 & -0.15 & I.45 \\
Weaving & & & & & & \\
I830-40 & 8.57 & 4.11 & 0.54 & 0.13 & 0.36 & 3.43 \\
I840-50 & 9.68 & 4.81 & 0.29 & 0.27 & 0.31 & 4.02 \\
I850-61 & 2.93 & 2.22 & 0.09 & -0.16 & -0.29 & 1.07 \\
I830-6I & 6.93 & 3.84 & $0.4 \mathrm{I}$ & 0.22 & 0.06 & 2.40 \\
\hline \hline
\end{tabular}

Notes and sources: See Appendix 3.

and more immediate. Therefore, with relatively low investments in physical and human capital, leading European regions could grow.

\section{Concluding remarks}

The overall balance-sheet of human capital in Catalonia during the emergence of the factory system is still uneven. On the one hand, the level of human capital present in the cotton industry was enough to adapt most modern foreign technologies and to fill skilled posts in new factories with native workers. For instance, after a short period of training in new technologies, all machinery-maintenance posts were filled by Catalan workers. On the other hand, no less important is the fact that human capital shows itself to contribute little to output growth; in other words, the overall level of human capital in the cotton industry did not rise much during the period.

The presence of this initial stock of human capital is one major explanation for why the economic and political crisis of the first thirty years of the nineteenth century was not enough to impede Catalan industrialisation. In all likelihood, the main development advantage of Catalonia over other Spanish and European regions was, precisely, this stock of human capital. ${ }^{28}$ Therefore, it is possible on the basis of the evidence presented to make some observations with regard to proto-industrialisation theory. In the original

${ }^{28}$ Mitch (I990, p. 33) has said: 'Successful industrialisers commonly drew on a stock of workers skilled in more traditional artisanal methods, while economies that had difficulty industrialising may have encountered problems because of the restricted supply of workers whose skills were acquired on the job'. 
formulation by Franklin Mendels, the main contribution of proto-industry to the new industry was in terms of the unskilled labour force (Mendels 1972). In other words, proto-industry furnished the new factories with abundant and cheap labour. On the contrary, the evidence for Catalonia suggests that proto-industry provided the new Catalan factories with the necessary human capital to introduce the new technologies. It was possible to adapt prior training to the technical requirements of the factories because between proto-industrial and factory technologies there were more similarities than differences, and some new factory technologies were also adapted to a proto-industrial use (Berg 1985 ).

A methodological corollary to this growth-accounting exercise is that one must be sceptical about the restriction of the concept of human capital to that of formal education during almost all of the nineteenth century. Thus, it is important to appreciate that the emergence of the factory system during the past century has the potential of filling some important gaps in the historical analysis of human capital. In truth, it shows that the 'educational' definition of human capital is very restrictive because the role of formal education (schooling) was limited in many proto-industrial households, factory jobs and, by extension, during the early phases of industrialisation. While a vast literature, accumulated over the last decades, contains a wealth of findings on the growth rates of schooling (enrolment or participation rates), corresponding estimates of on-the-job training and learning have not been constructed. Instead, the growth of participation or enrolment rates has been assumed to reflect human capital accumulation during the nineteenth century.

Finally, the limitations of the model employed in the emergence of the Catalan factory system should also be stressed. In reality, this model was not able to sustain a new shift in the output and in the quality of production in the long term because the Catalans were not able to produce original technology with their stock of human capital. Therefore, Catalan industrial firms were only capable of adapting and modifying foreign technologies with more similarities than differences with the technologies employed at that moment. Only with the development of formal technical training could the Catalans develop this innovative capacity in the long term. Entrepreneurs were aware of this problem and one of them said to a government commission in 1867 (Comisión especial arancelaria 1867, p. 83):

Our managers had to make use of several technicians from foreign countries. The indifference in Spain towards the study of applied mathematical and natural sciences impedes our industrial firms in organizing a numerous and sufficient national skilled workforce in order to satisfy all production requirements. It should be acknowledged that this (skilled workforce) is a main element for the development and the prosperity of any kind of industry and that it had to be found at any cost even out of our borders, where it is abundant. 


\section{Acknowledgements}

The present article is the full revision of a draft paper presented at the Conference 'Controversies in European Economic History' held in Copenhagen in November 1996. Helpful comments and suggestions have been received from Ann Carlos, René Leboutte, David Mitch, Clara Eugenia Nuñez, Jaime Reis, who strongly encouraged this article, the participants at the Copenhagen Conference, and the referees and editors of this journal. All remaining errors are mine.

\section{References}

Abramovitz, M. (1993). The search for the sources of growth: areas of ignorance, old and new. Fournal of Economic History 53(2), pp. 217-43.

Arau, N. (1855). Tratado Completo de la Hilatura del Algodón. Barcelona: Luis Tasso.

Barro, R. J. and Sala-I-Martin, X. (1992). Convergence. Fournal of Political Economy I00, pp. 223-52.

Barro, R. J. and Sala-I-Martin, X. (1994). Economic Growth. New York: McGraw-Hill.

BECKER, G. (1962). Investment in human capital: a theoretical analysis. Fournal of Political Economy 70, pp. 9-49.

BERG, M. (1985). The Age of Manufactures: Industry, Innovation and Work in Britain. Oxford: Oxford University Press.

Boot, H. M. (1995). How skilled were Lancashire cotton factory workers in 1833 ? Economic History Review 48, pp. 283-303.

Calvet, D. (1857). Sección práctica: Hilatura de Algodón. Revista Industrial. CAmps, E. (1995). La Formación del Mercado de Trabajo Industrial en la Cataluña del Siglo XIX. Madrid: Ministerio de Trabajo.

CerdA, I. (1968 [1867]). Monografía Estadística de la Clase Obrera de Barcelona en 1856. Madrid: Instituto de Estudios Fiscales.

COMISIÓN ESPECIAL ARANCELARIA (1867). Información sobre el derecho diferencial de bandera y sobre los de aduanas exigibles a los hierros, al carbón de piedra y los algodones, presentada al gobierno de Su Majestad por la comisión nombrada al efecto en Real Decreto de Io de noviembre de 1865. Madrid: Imprenta Nacional.

COMISIÓN DEL GOBIERNO DE S.M. (I84I). Informe sobre algodones en rama y manufacturados que dió al Ministerio de Hacienda, con fecha 8 de agosto de I840, una comisión nombrada por la funta Revisora de los Nuevos Aranceles. Madrid: Imprenta Nacional.

COMISIÓN DE FÁBRICAS (1846). Exposición razonada que en forma de cartas dirige al Excelentisimo Señor Ministro de Hacienda la Comisión de fábricas. Barcelona: Imprenta y Libreria Oriental.

CRAFTs, N. F. R. (1995). Exogenous and endogenous growth? The Industrial Revolution reconsidered. Fournal of Economic History 35, pp. 745-72.

Ferrer VIDAL, J. (I875). Conferencias sobre el Arte de Hilar y Tejer en general y especialmente sobre el de Hilar y Tejer el Algodón. Barcelona: Jaime Jepús Roviralta. Figuerola, L. (I968 [1849]). Estadística de Barcelona en I849. Madrid: Instituto de Estudios Fiscales. 
Garrabou, R., Pujol, J. and Colomé, J. (I99I). Salaris, ús i explotació de la força de treball agrícola (Catalunya, I818-1936). Recerques 24, pp. 23-74.

Gutiérrez, M. M. (1834). Comercio Libre o Funesta Teoria de la Libertad Económica Absoluta. Madrid: M. Calero.

Gutiérrez, M. M. (I837). Impugnación a las Cinco Proposiciones de Pebrer sobre los Grandes Males que Causa la Ley de Aranceles a la Nación en General, a la Cataluña en Particular, y a las Mismas Fábricas Catalanas. Madrid: M. Calero.

GoldiN, C. and KATZ, L. W. (I996). The origins of technology-skill complementarity. NBER Working paper 5657.

Huberman, M. (I99I). How did labor markets work in Lancashire? More evidence on prices and quantities in cotton spinning, 1822-52. Explorations in Economic History 28, pp. 87-120.

Huberman, M. (1996). Escape from the Market. Cambridge: Cambridge University Press.

IZARD, M. (1969). La Revolución Industrial en España: Expansión de la Industria Algodonera Catalana, I832-6I. Mérida (Colombia): Universidad de los Andes. JunTA DE FÁbricas (1830). Carta al Subsecretario de Policía, Io October I830. Arxiu del Foment del Treball Nacional (hereafter AFTN) registro de oficios. Unpublished. JUNTA De FÁbricas (I833). Carta a José Bonoplata, i I December I833. AFTN registro de oficios. Unpublished.

Junta de FÁbricas (I834a). Carta al Intendente del Pricipado de Cataluña, 4 January I834. AFTN registro de oficios. Unpublished.

JunTA de Fábricas (1834b). Informe a la Junta de Comercio, 30 March I834. AFTN registro de oficios. Unpublished.

JUNTA DE FÁBRICAS (1835). Cara al Alcalde mayor, 6 October I835. AFTN registro de oficios. Unpublished.

JuNTA DE FABricas (I850). Censo de fábricas de I850. AFTN. Unpublished. LAZONICK, W. (1979). Industrial relations and technical change: the case of the self-acting mule. Cambridge fournal of Economics 3, pp. 23I-62.

LuCAs, R. E. JR. (1988). On the mechanics of economic development. Fournal of Monetary Economics 22, pp. 3-42.

LUCAS, R. E. JR. (I990). Why doesn't capital flow from rich to poor countries? American Economic Review 80, pp. 92-6.

MADOz, P. (1846). Diccionario geográfico-estadistico-histórico de España y sus posesiones de ultramar. Madrid.

MALUQuer, J. (1976). La estructura del sector algodonero en Cataluña durante la primera etapa de la industrialización (1832-6I). Hacienda Pública Española 38, pp. I33-48.

Mankrw, G. N. (1995) The growth of nations. Discussion Paper I73I. Harvard Institute of Economic Research.

MANKrw, G. N., Romer, D. and WeIL, D. (1992). A contribution to the empirics of economic growth. Quarterly fournal of Economics 107, pp. 285-307.

Mendels, F. (1972). Proto-industrialisation: the first phases of the process of industrialisation. Fournal of Economic History 32, pp. 24I-6I.

MINCER, J. (1974). Schooling, Experience and Earnings. New York: Columbia University Press. 
MINCER, J. (1989). Job training: costs, returns and wage profiles. Working paper 3208, NBER.

MrTCH, D. (I990). Education and economic growth: another axiom of indispensibility? From human capital to human capabilities. In G. Tortella (ed.), Education and Economic Development since the Industrial Revolution. Valencia:

Generalitat Valenciana, pp. 29-45.

NADAL, J. (1974). El fracaso de la Revolución Industrial en España. Barcelona:

Ariel.

NAdAl, J. (I991a). La indústria cotonera. In Nadal, J., Maluquer, J. and Cabana, F. (eds) Història econòmica de la Catalunya contemporània. Barcelona: Enciclopèdia Catalana 3, pp. I2-85.

Nadal, J. (I99Ib). La metallúrgia. In J. Nadal, J. Maluquer and F. Cabana (eds). Història econòmica de la Catalunya contemporània 3. Barcelona: Enciclopèdia Catalana, pp. 159-202.

NuÑez, C. E. (1992). La Fuente de la riqueza. Educación y desarrollo económico en la España Contemporánea. Madrid: Alianza Universidad.

REBELLO, S. (I99I). Long-run policy analysis and long-run growth. Fournal of Political Economy 99, pp. 500-2I.

ROMER, P. (1986). Increasing returns and long-run growth. Fournal of Political

Economy 94, pp. 1002-37.

Ronquillo, J. O. (I85I-7). Diccionario de Materia Mercantil, Industrial y Agricola. Barcelona: Imp. Gaspar.

Rosenberg, N. (1982). Inside the Black Box: Technology and Economics.

Cambridge: Cambridge University Press.

SANDBERG, L. (1979). The case of the impoverished sophisticate: human capital and Swedish economic growth before World War I. fournal of Economic History 39, pp. 225-4I.

SANDBERG, L. (1982). Ignorance, poverty and economic backwardness in the early stages of European industrialisation: variations on Alexander Gerschenkron's grand theme. Fournal of European Economic History II, pp. 675-97.

SAYRÓ, E. (1842). Industria Algodonera de Cataluña, Madrid: Imprenta Nacional. SCHULTZ, T. W. (1962). Reflections on investment in man. Fournal of Political Economy 70, pp. I-7.

SIcsic, P. (1994). Establishment size and economies of scale in I9th-century France. Explorations in Economic History 3I, pp. 453-78.

Young, A. (1995). The tyranny of numbers: confronting the statistical realities of the east Asian growth experience. Quarterly fournal of Economics IIO, pp. 64I-80. 


\section{Appendix I: Methods and sources for estimates of full-time equivalent employment (FTE)}

The absence of good sources on employment adjusted to work-hours make it necessary to develop an indirect method for calculating these numbers. The total number of FTE in the year $t$ has been computed by multiplying the amount of functioning machinery in the year $t$ by positions per machine. Each FTE is equivalent to $3,185.5$ hours (II.5 hours $\times 277$ working days per year). It should be noted that positions per year and machine are different for each type of machinery and they have been derived directly from different contemporary sources. Thus, for example, I actually estimate the I850 FTEs in mechanical looms using the number of functioning mechanical looms in 1850 and the positions per mechanical loom. For my overall FTE estimates, I then sum across different types of machinery. A main advantage of this method is that the number of hours obtained is adjusted for periods when factories were at a standstill; thus the FTEs are correlated with movements in output. Therefore, the figures obtained do not reflect the number of workers; on the contrary, they represent the real hours worked. The data on positions per machine are drawn from Madoz (I846), Cerdá (I968), Comisión especial arancelaria (1867), and Ferrer Vidal (1875). It is important to appreciate that different sources give very similar positions per machine. Finally, Figuerola (1968), Sayró (1842), Junta de Fábricas (1850), and Comisión especial arancelaria ( 1867 ), respectively, provided data on functioning machinery for $1830,1840,1850$ and $\mathrm{r} 86 \mathrm{r}$.

\section{Appendix 2: Methods and sources for estimates of skills composition}

My task is to estimate the labour force cross-classified by up to seven skills attributes. First, I separate the workforce between proto-industry and factory workers. This separation has been established under the assumption that workers who used hand machinery were proto-industry workers and that workers who used other machinery were factory workers. Therefore, to obtain the number of FTE in proto-industry, I multiply the amount of functioning hand machinery by positions per year per machine. Then, I make use of the information provided by the sources to divide the resulting figures into males, females and children. However, it should be noted that proto-industry categories are heterogeneous since there were some that were low skilled while others were skilled. Gutiérrez (1834) and Figuerola (1968), Madoz (I846), Junta de Fábricas (I850) and Comisión especial arancelaria (1867), respectively, provided the data on hand-machinery for $1830,1840,1850$ and I86I.

Second, I make use of the information provided by several historical sources on the occupations associated with each type of machinery to divide factory workers into several skills categories. Thus, for example, I actually estimate the FTE in I86I of self-actings cross-classified by sex and skills, üsing available sources. For my final estimates, I then sum across different machinery to derive a reduced table of the variables of interest to me. Estimates of the working population crosstabulated by class of machinery, sex, and skills were derived from Comisión de Fábricas (I846), Cerdá (1968), and from Comisión especial arancelaria (1867). 
Note that for 1830 , skills by type of machine were assumed to be those reported in the 1840 data, the earliest year for which detailed data is available. Finally, it should be noted that, in weaving, only factories were important by the I850s and that the different sources give very similar pictures of the skills composition of the workforce.

\section{Appendix 3: Methods and sources for growth accounting}

Output: Divisia index of output with six homogeneous categories of product. Spinning quantities are based on yearly imports of raw cotton with variable wastage calculated according to the method of Huberman (1996, pp. 107-9). Weaving figures are yarn production minus yarn employed by the mixed fabrics and hosiery industries. Imports of raw cotton from Nadal (1974) and Diario de Barcelona (1866), Almanaque para 1867. Prices of cotton goods from Ronquillo (I85I-7) and Diario de Barcelona (1866).

Physical inputs: Divisia index of inputs with five homogeneous categories plus energy. Sources for raw cotton, Izard (1969) and Diario de Barcelona (I866); for energy Madoz (1846), Sayró (1842), and Comisión especial arancelaria (1867). Sources for yarn are the same as for output figures in the spinning industry.

Physical capital: Divisia index of real capital with six homogeneous categories (factories, workshops, modern machinery, hand machinery, engines, and inventories) weighted with rental rates (with geometric depreciation). The results are robust to changes in depreciation rates and alternative rental rates. The sources are: for 1830, Gutiérrez (1834) and Figuerola (1986); for I840, Sayró (1842) and Madoz (1846); for 1850, Junta de Fábricas (1850); and for I86I, Comisión especial arancelaria (1867) and Gimenez Guited (1862), Guia fabril e industrial de España, Barcelona.

Human capital: Divisia index of real human capital with 56 categories (cohort $\times$ sex $\times$ skills) weighted with relative incomes exceeding the raw labour wage.

My first task is to estimate the working population, cross-classified by up to three attributes, i.e. sex, age and skills. Under the assumptions that the life expectancy of all kinds of workers is the same and that they remained in the industry all their lives, I derive an approximation of the age distribution of the workforce for each benchmark year (1830, I840, 1850, I86I).$^{29} \mathrm{I}$ use three sets of numbers: the total number of FTE in each benchmark year, the age distribution of the Catalan cotton industry workforce, and the survival tables for Catalonia. The total number of FTE is in Table 2. The age distribution of the Catalan cotton industry workforce is drawn from Camps (1995), table I0, p. I66, Barnosell, G., Camps, E., García, A., Muñoz, L. and Roses, J. R. (1994). Occupación, productividad y salarios: una reflexión para el caso catalán (1850-1913) (mimeo) and Ferrer, L. (1994) Notas sobre la familia y el trabajo de la mujer en la Cataluña (siglos XVIII-XX). Boletin de la Asociación de Demografia Historica 12, pp. 199-232. It should be noted that the age distribution is different for proto-industry and factory workers. Finally, the survival tables are

29 Because age-specific mortality was higher for unskilled than skilled workers, my first assumption will produce an underestimate of human capital. By contrast, the second assumption will produce an underestimate of human capital to the extent that workers left the cotton industry. 
drawn from Muñoz, F. (I99I). Proyección inversa y estimación indirecta de la mortalidadad: resultados para un grupo de localidades catalanas. Boletin de la Asociación de Demografia Histórica 9, pp. 67-86.

The second task is to estimate the remuneration of human capital in each category of workers. I begin by constructing estimates of the average hourly incomes of employees cross-tabulated by industry (proto-industry and factory, spinning and weaving), adult-children, sex, and skills. I then use the figures of Camps (1995, pp. 198-204) on wage profiles for highly skilled, skilled, unskilled, male and female workers to estimate the variation in incomes of employees due to age. Therefore, relative incomes by worker age are assumed to be constant at the levels reported in Camps (1995). Finally, I deduct the part of remuneration that corresponds to raw labour (initial hourly wages of workers; that is, the minimum wage at each occupation). The sources are: for $1830 \mathrm{Madoz}$ (I846) and Junta de Fábricas (I846), for $1840 \mathrm{Madoz}$ (I846) and Junta de Fábricas (I846), for I850 Cerdá (I968) and for I86I Comisión especial arancelaria (1867).

Raw Labour: Unweighted hours worked (see Appendix I).

Shares: Current values at wholesale prices minus taxes. Capital share has been computed as the residual of total value minus physical inputs, human capital, and raw labour values. 